\title{
Development of Learning Devices Oriented Problem Based Learning to Increase Student's Combinatorial Thinking in Mathematical Problem Solving Ability
}

\author{
Ammamiarihta \\ Department of Mathematics Education \\ Universitas Negeri Medan \\ Medan, Indonesia \\ Corresponding Email: amma.ririn@gmail.com \\ Edi Syahputra \\ Department of Mathematics Education \\ Universitas Negeri Medan \\ Medan, Indonesia \\ Edy Surya \\ Department of Mathematics Education \\ Universitas Negeri Medan \\ Medan, Indonesia
}

\begin{abstract}
This research study is research and development learning devices. This study aimed to describe how the validity, practically, and effectiveness of learning devices oriented of problem based learning which is developed and knowing about increase students' combinatorial thinking in mathematical problem solving ability after using learning devices which is developed. The product that produce in this study is lesson plan, handbook's teacher, student's book, and worksheet. Learning devices development using 4D model which developed by Thiagarajan, Semmel and Semmel with four step, that is define, design, develop and disseminate. This study was conducted in two trials in two different class . Data was analyzed descriptive and result of research showed the devices was categorized valid both in terms of content and construct, practical to use, and effective and students' combinatorial thinking in mathematical problem solving ability increased by using learning devices which developed. The increasing of students' ability seen from the result of test in trial I and trial II were increase about $6,67 \%$.
\end{abstract}

Keywords-Learning Devices, Problem Based Learning, Combinatorial Thinking.

\section{INTRODUCTION}

Learning devices is the most important component that must be prepared by the teacher before implementing the learning process.Before the teacher taught (preparatory step) a teacher is expected to prepare materials that will be taught, preparing props to be used, preparing questions and directions to lure students to actively learn, learn the state of students, and learn the initial knowledge of students, all this will unravel its implementation in the learning device[1] Learning devices should not only provide materials instantly, but be able to lead students to the ability to understand learned concepts. It aims to determine the extent to which learning devices have been presented, what indicators to be achieved, to how the follow-up will be done by the teacher.

In the development of quality learning devices need an assessment of products developed. In order to make the concept "quality" more transparent, it was related to a topology of curriculum representations, resulting in framework with three quality criteria: validity, practicality, and effectiveness [2]. So, to determine the quality of the development of learning devices required three criteria: validity, practicality, and effectiveness.

Learning devices are expected to facilitate students in understanding the material learned primarily on mathematic materials that tend to be considered difficult by students. Learning math is a high-level mental activity [3]. Therefore, mathematics learning devices developed should also be able to assist students in developing students 'thinking skills, students are involved in building ideas, principles and mathematical structures based on students' own experience.

Piaget in his intellectual development level theory reveals for children over the age of 11 years already at the formal operational level of thinking [4]. There are five levels of formal operation: Proportional reasoning, 
Controlling variables, Probabilistic reasoning, Correlational reasoning, and Combinatorial reasoning [5]. The third formal operational thinking characteristic is combinatorial thinking, ie thinking encompasses all possible combinations of objects, ideas, or propositions[4].

Combinatorial thinking is a process of finding a number of alternatives to solving a discrete problem. Combinatorics is an important topic to taught and discussed in depth with students in the classroom. The first reason is that combinatorics do not require the preconditions of calculus, so this topic can be taught early, independent of student mastery over the calculus. Then also combinatorics can be used to train students to calculate, make estimates, generalize, and think systematically. Combinatorics can be applied in many other fields such as programming, physics, and engineering as well as other disciplines. Combinatorics can lead students to understand the strengths and limitations of mathematics. In addition, combinatorics play an important role in the science of arithmetic [6].

The students difficulties in solving the combinatoric problems are caused by a lack of students understanding of the given problem. Students also have a difficulty in relation to permutation and combination [7]. Combinatorics is a field that most pupils find very difficult. Two fundamental steps for making the learning of this subject easier are understanding the nature of pupils' mistakes when solving combinatorial problems and identifying the variables that might influence this difficulty [8].

Students' understanding of the problem is very helpful for students in solving combinatorial problems. To be able to improve students' combinatrorial thinking skills, problem solving skills must first be raised. In the problemsolving process, students' combinatorial reasoning ability can be trained. Combinatorics provides a student collaborative situation to develop verbal and written skills in the process of solving problems [6]. So that, it is necessary a way for students to always be involved in problem solving that involves the process of combinatorial thinking. This relates to the appropriate learning model to be used in the learning process.

Teachers are required to choose a learning model that can spur the spirit of students to be actively involved in the learning experience. Learning should emphasize active involvement of students in understanding mathematical concepts or principles to enable learning to be meaningful, students learn not only to learn about, but also learn to do, learn to be, learn to learn, and learning to live together. Therefore, one of the models that can be used is the Problem Based Learning model.

Problem based learning model is a concept of learning centered on authentic issues so that students can develop their own knowledge, cultivate high-level thinking skills and inquiry, establish students and increase confidence [9]. In addition, Problem Based Learning model is also helps students develop inquiry and problem solving ability to give students experience with adult roles and enable them gain confidence in their ability to think, and make them selfregulating learners [10]. This approach involves inferring information around the problem, synthesizing and representing what one gets to others. In Problem Based Learning, students are faced with challenging problems that can present students' thinking activities in solving cooperative math problems in small group discussions and reinforce mathematical ideas in shaping new understandings. In the process of discussion and presentation is expected to open the opportunity in an effort to increase students' combinatorial thinking ability, which in turn will be able to increase the quality of mathematics learning.

Based on the problem that has been described, the purpose of this research are: 1) to develop the learning devices using Problem Based Learning that fulfill the valid, practical and effective criteria, 2) to describe the improvement of students' combinatorial thinking ability by using the learning devices.

\section{LITERATURE}

\section{A. Combinatorial Thinking}

Combinatorial thinking is the ability to consider all possible alternatives in a given situation. The child while solving a problem will use all combinations or factors that are related to a particular problem. Combinatorial thinking as a tool for solving problems if children doing geometrical tasks was experimented. The pupils must use their combinatorial thinking and find a systematic to be sure that all possibilities have been discussed [11]. Combinatorial thinking is a special aspect of mathematical thinking.

Students' understanding of the problem is very helpful for students in solving combinatorial problems. Effects of various factors influencing students' performance in solving combinatorial problem within all four steps of of Polya's (1957) problem-solving cycle were studied (understanding the problem, making a plan, carrying out the plan and looking back) [12]. To be able to improve the ability of combinatrorial thinking students needed process troubleshooting in the process. In the problem-solving process, students' combinatorial reasoning ability can be trained.

\section{B. Problem Based Learning Model}

Problem Based Learning is a learning that uses real-world problems as a context for learners to learn about critical thinking and learning ability in solving problems, and to acquire essential knowledge and concepts from subject matter [13]. Problem Based Learning also helps students develop investigative and problem solving ability to give students experience with adult roles and enable them to gain confidence in their ability to think, and make them self-governing learners problems are given to students, before students learn concepts or materials relating to problems to solve [9]. Problem Based Learning is an instructional approach, which use problem to trigger learning. Students are in-group to work collaboratively to search resolution of the problem. Teacher plays his role to facilitate learning with scaffolding technique by giving indirect hints or posing stimulated. 
Problem-based learning uses five main stages: student orientation to the problem, organizing students to learn, guiding individual and group investigations, developing and presenting the work and analyzing and evaluating the process solution to problem [14].

\section{METHODE}

This research includes depelopment research using 4-D model of development Thiagarajan, Semmel, and Semmel (1974). Subjects in this study were students of grade XI of SMA Istiqlal Delitua 2016/2017 academic year, whereas the object of this research were learning devices using problem based learning. Trial 1 was done in class XI IPA 2 and trial 2 was done in class XI IPA 3.

Learning devices developed in this study were lesson plans, handbook's teacher, student's book, student's, and worksheets. Instrumen for collecting data in this stufy are tests, questioners and observation sheets. Developing learning devices was done by using the 4-D model which consisted of 4 steps that were define, design, develop and disseminate.

\section{A. The Validity of Learning Devices}

Learning devices are said to be valid if they meet the criteria of content validity and construct validity. The validity of content was done by 5 validators by giving score 1 to 5 in each assessment column based on aspects: 1) format, 2) language, 3) content, and 4) illustrations. Furthermore the overall expert assessment was processed by calculating the average score to obtain the criteria of content validity assessment and will be outlined in Tabel 1 .

Learning devices have been revised based on input from experts and samples tested outside of the classroom in order to get eligible subjects. Then, the test results are analyzed for validity and reliability. The formula used to calculate the validity is the product moment correlation [15].

$$
r_{x y}=\frac{N \sum x y-\left(\sum x\right)\left(\sum y\right)}{\sqrt{\left\{N \sum x^{2}-(x)^{2}\right\}}\left\{N \sum y^{2}-\left(\sum y\right)^{2}\right\}}
$$

Note:

$r_{x y}$ : correlation coefficient between variable $x$ and $y$

$X$ : score items

$Y$ : total score

$N$ : the number of students who take the test (sample)

Then, to determine the coefficient of reliability of a test used in narrative form alpha formula [15], as follows:

$$
\propto=\left(\frac{k}{(k-1)}\right)\left(1-\frac{\sum \sigma_{h}^{2}}{\sigma_{t}^{2}}\right)
$$

Note:

$\propto \quad$ : reliability coefficient test

$\mathrm{k} \quad$ : the number of test items

$\sum \sigma_{h}^{2}:$ the number of variance test scores of each item

$\sigma_{t}^{2} \quad$ : total variance
TABLE 1. Rate Validity Criteria of Learning Devices

\begin{tabular}{|c|c|}
\hline Average Validity (Va) & Criterion Validity \\
\hline $1 \leq V a<2$ & Invalid \\
\hline $2 \leq V a<3$ & Less valid \\
\hline $3 \leq V a<4$ & Enough valid \\
\hline $4 \leq V a<5$ & Valid \\
\hline$V a=5$ & Veryvalid \\
\hline
\end{tabular}

TABLE 2. Qualification Percentage of Learning Implementation

\begin{tabular}{|c|c|}
\hline $\begin{array}{c}\text { The Percentage of the } \\
\text { implementation }(\mathbf{k})\end{array}$ & Category \\
\hline$k \geq 90$ & Very Good \\
\hline $80 \leq k<90$ & Good \\
\hline $70 \leq k<80$ & Fair \\
\hline $60 \leq k<70$ & Poor \\
\hline$<60$ & Very Poor \\
\hline
\end{tabular}

\section{B. The Practicality of Learning Devices}

The practicality of the learning devices was observed based on the validator's assessment and the implementation of learning devices. The validator assessment criteria are met if it is found on the validation sheet that all validators states that learning devices can be used with "a few revisions" or "no revision".

Furthermore, the learning devices implementation was observed based on the observer's assessment where they chose score 1 to 5 on each aspect of learning devices implementation that were lesson plans, handbook's teacher, student's book, and worksheets. The average total score obtained was categorized into the percentage of learning implementation and will be outlined in Tabel 2 .

\section{The Effectiveness of Learning Devices}

The effectiveness of learning devices was observed based on students' active activity meets the criteria of achieving the percentage of ideal time set, mastery of students' combinatorial thinking ability clasically, that is minimum $85 \%$ student follow learning able to reach score, and $80 \%$ students give positive responses to learning devices.

\section{RESULT}

\section{A. Define}

The purpose of learning can be identified by first analyzing instructional needs. The process of identifying instructional needs begins with identifying problems in the field. Based on preliminary observations, students' combinatorial thinking ability are still low. This is also supported by the state of teachers who have not been able to develop learning materialls that focus to increase students' combinatorial thinking ability. Based on these findings, the main purpose of developing this devices are to develop learning devices to improve students' combinatorial thinking in mathematical problem solving ability. 


\section{B. Design}

The main activity of this step was to write the initial draft of learning devices including the lesson plans, handbook's teacher, students' books, worksheets, and test of combinatorial thinking ability. The instructional devices were based on $\mathrm{KI}, \mathrm{KD}$, and indicators on combinatoric material, and adjusted to the purpose of learning and improving combinatorial thinking ability.

\section{Develop}

In this step, implemented learning by using learning devices with model problem based learning that developed in the classroom.

\section{1) Validity}

At this stage content validity and construct validity are performed. Content validity is done by 5 validators. Validation results by the validator indicate that all learning devices developed have met the valid criteria with a total average value of lesson plan validity of 4.38, handbook's teacher of 4.41 , student books 4.40 , and worksheet validity 4.43 , test of combinatorial thinking ability has been in valid category. While the validity of constructs obtained by providing tests of combinatorial thinking to students who have learned the devices. The result of construct validity indicates that the test grain of combinatorial thinking is valid. Then calculated the reliability of the test items of combinatorial thinking ability.

\section{2) Practically on trial 1}

The first criterion of practicality has been met as all validators assume that the developed learning devices can be used with little revision. This assessment is given to experts and practitioners at once with the provision of materials validation sheets. The second criterion of practicality has also been fulfilled, the percentage of learning devices implementation reaches $81.46 \%$ (good category). The implementation of the learning devices used is reviewed at each meeting. The implementation of all learning devices used in the research is observed by an observer who is a teacher of mathematics studies at every meeting conducted. Thus, learning devices developed in trial 1 can be said to be practical.

\section{3) Efektiveness on trial 1}

The first criterion of effectiveness is the mastery of students' combinatorial thinking ability in class and it is

TABLE 3. Average Percentage of Ideal Time of Student Activity

\begin{tabular}{|l|c|c|c|c|c|}
\hline \multirow{2}{*}{ Meeting } & \multicolumn{5}{|c|}{ Frequency For Each Type of Activity } \\
\cline { 2 - 6 } & $\mathbf{1}$ & $\mathbf{2}$ & $\mathbf{3}$ & $\mathbf{4}$ & $\mathbf{5}$ \\
\hline I (2 x 45') & 20,00 & 17,78 & 27,78 & 28,89 & 5,56 \\
\hline II (2 x 45') & 23,33 & 15,56 & 31,11 & 25,56 & 4,44 \\
\hline III (2 x 45') & 21,11 & 13,33 & 33,33 & 28,89 & 3,33 \\
\hline Average & $\mathbf{2 1 , 4 8}$ & $\mathbf{1 , 5 6}$ & $\mathbf{3 0 , 7 4}$ & $\mathbf{2 7 , 7 8}$ & $\mathbf{4 , 4 4}$ \\
\hline Criterion & $\begin{array}{c}20 \% \\
\leq \mathrm{PWI} \leq \\
30 \%\end{array}$ & $\begin{array}{c}10 \% \\
\leq \mathrm{PWI} \leq \\
20 \%\end{array}$ & $\begin{array}{c}25 \% \\
\leq \mathrm{PWI} \leq \\
35 \%\end{array}$ & $\begin{array}{c}25 \% \\
\leq \mathrm{PWI} \leq \\
35 \%\end{array}$ & $\begin{array}{c}\leq \mathrm{PWI} \leq \\
5 \%\end{array}$ \\
\hline
\end{tabular}

found that 24 students complete $(80 \%)$ and 9 non students (20\%) from 30 students who followed postest of mathematical combinatorial thinking.

The second criterion of effectiveness is student's activity fulfills ideal time percentage and it is found that there are all categories (category 1, 2, 3, 4 and 5) that have reached percentage of ideal time in trial 1 . The average percentage of ideal time of student activity time in trial 1 will be outlined in Table 3 .

The third criterion of effectiveness is student's positive response and it is found that the average percentage of student's response is above $80 \%$. So it can be concluded that the student's response is in positive category.

Based on the above description it can be concluded that the learning devices has not met the criteria effectively so that it needs to be revised to some learning devices components developed with the hope of problem based learning material can improve the ability of students' combinatorial thinking on trial 2.

\section{4) Practically on trial 2}

The first criterion of practicality has been met as all validators assume that the developed learning devices can be used with little revision. This assessment is given to experts and practitioners at once with the provision of devices validation sheets. The second criterion of practicality has also been fulfilled, the percentage of learning devices implementation reaches $85,14 \%$ (good category). The implementation of the learning devices used is reviewed at each meeting. The implementation of all learning devices used in the research is observed by an observer who is a teacher of mathematics studies at every meeting conducted. Thus, the learning devices developed in trial 2 can be said to be practical.

\section{5) Efektiveness on trial 2}

The first criterion of effectiveness is the mastery of students' combinatorial thinking ability in class and it is found that 26 students complete $(86.67 \%)$ and 4 students not complete $(13.33 \%)$ from 30 students who followed postest of combinatorial thinking. Thus, the posttest result of students' combinatorial thinking ability in trial 2 fulfilled the classical completeness. So it can be concluded that the completeness of the ability of combinatorial thinking has been classically met.

The second criterion of effectiveness is student's activity fulfills ideal time percentage and it is found that that all categories of student activity have reached the percentage of ideal time set. So it can be concluded that the percentage of ideal time student activity on trial 2 already meet the criteria of achieving the percentage of ideal time set. The average percentage of ideal time of student activity time in trial 2 will be outlined in Table 4.

The third criterion of effectiveness is student's positive response and it is found that the average percentage of student response aspect is above $80 \%$. So it can be concluded that the student response is in positive category. 
TABLE 4. Average Percentage of Ideal Time of Student Activity

\begin{tabular}{|l|c|c|c|c|c|}
\hline \multirow{2}{*}{ Meeting } & \multicolumn{5}{|c|}{ Frequency For Each Type of Activity } \\
\cline { 2 - 6 } & $\mathbf{1}$ & $\mathbf{2}$ & $\mathbf{3}$ & $\mathbf{4}$ & $\mathbf{5}$ \\
\hline I (2 x 45') & 18,89 & 16,67 & 32,22 & 28,89 & 3,33 \\
\hline II (2 x 45') & 21,11 & 17,78 & 31,11 & 27,78 & 2,22 \\
\hline III (2 x 45') & 22,22 & 15,56 & 30,00 & 30,00 & 2,22 \\
\hline Average & $\mathbf{2 0 , 7 4}$ & $\mathbf{1 6 , 6 7}$ & $\mathbf{3 1 , 1 1}$ & $\mathbf{2 8 , 8 9}$ & $\mathbf{2 , 5 9}$ \\
\hline Criterion & $\begin{array}{c}20 \% \\
\leq \mathrm{PWI} \leq \\
30 \%\end{array}$ & $\begin{array}{c}10 \% \\
\leq \mathrm{PWI} \leq \\
20 \%\end{array}$ & $\begin{array}{c}25 \% \\
\leq \mathrm{PWI} \leq \\
35 \%\end{array}$ & $\begin{array}{c}25 \% \\
\leq \mathrm{PWI} \leq \\
35 \%\end{array}$ & $\begin{array}{c}0 \% \\
\leq \mathrm{PWI} \leq \\
5 \%\end{array}$ \\
\hline
\end{tabular}

Based on the above description it can be concluded that the learning devices has met the criteria valid, practical and effective.

\section{6) The Increasing of Combinatorial Thinking Ability}

The results of the increasing of the student's combinatorial thinking ability in the first and second trial class showed that the average of students' combinatorial thinking ability on the post-test result on trial 1 was 2.80 increased to 2.86 in trial 2 .

The improvement of students' combinatorial thinking ability is also seen from the increasing number of students who completed in post-test combinatorial thinking. This increase is seen from the number of students who completed the post-test trial I about $80 \%$ and trial II about $86.67 \%$ and the increasing is equal to $6.67 \%$.

Description of the improvement of students' combinatorial thinking ability by using problem-based learning devices was developed in trial 1 and 2 for each combinatoric model can be seen in Fig 1.

\section{Disseminate}

After the learning devices were valid, practical and effective is met at the end of trial 2, then the final devices is obtained. The next step is to do a limited distribution of final devices handover to SMA Istiqlal Delitua. Submission of learning material to SMA Istiqlal Delitua in the hope that the math teachers incorporated in the forum can apply the learning devices to the next lesson.

TABLE 5. Score of Student's Combinatorial Thinking Ability Test in Trial 1 and Trial 2

\begin{tabular}{|l|c|c|}
\hline \multicolumn{1}{|c|}{ Kategori } & Uji Coba 1 & Uji Coba 2 \\
\hline Skor tertinggi & 3,56 & 3,73 \\
\hline Skor Terendah & 1,78 & 1,78 \\
\hline Rara-rata & 2,80 & 2,86 \\
\hline Ketuntasan Klasikal & $80 \%$ & $86,67 \%$ \\
\hline
\end{tabular}

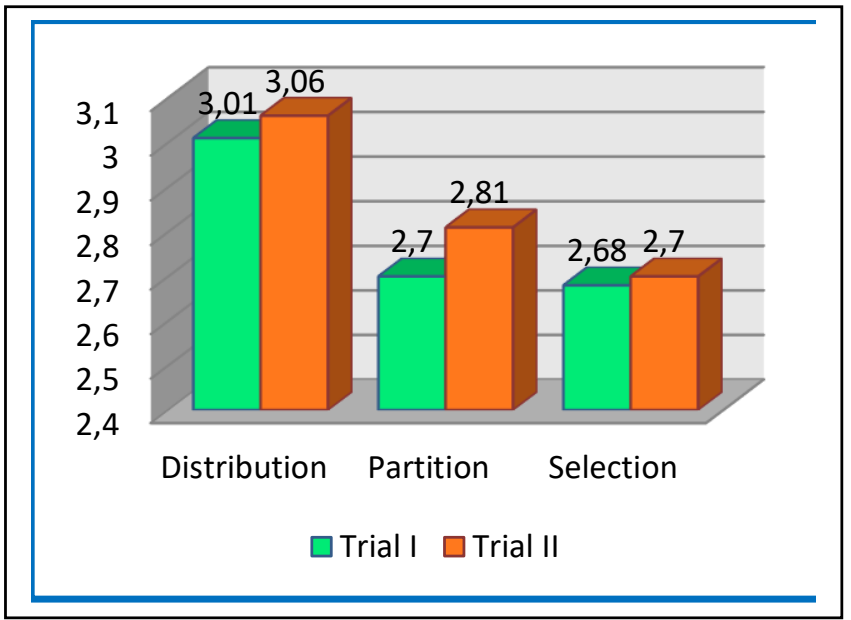

Fig. 1. Improvement for each combinatorial model

\section{CONCLUSION}

The validity of learning devices have met the valid criteria and item test combinatorial thinking ability in a valid category.

Learning devices have met the practical criteria in terms of the validator response to learning devices is good and can be used with little revision and the implementation of problem-based learning devices is good .

Learning devices have met the effective criteria in terms of the percentage of students' active activities during the learning process met the frame of ideal frame; (2) $86.67 \%$ of students's achieve mastery of students' mathematical representation ability calsically and (3) more than $80 \%$ of students who give positive responses to the components of leraning material.

Students' combinatorial thinking ability improved after learning by using learning devices was develop about $6,67 \%$.

\section{REFERENCES}

[1] Suparno, P. 2002. Teori Perkembangan Kognitif Jean Piaget. Yogyakarta: Kanisius.

[2] Nieveen, N. 1999. Prototyping to Reach Product Quality. In Jan Van den Akker, R.M. Branch, K. Gustafson, N. Nieveen \& Ti. Plomp (Eds). Design Approaches and Tools in Education and Training (pp 125-135). Dordrecht: Kluwer Academic Publishers.

[3] Hudoyo, H. 2003. Pengembangan Kurikulum dan Pembelajaran Matematika. Malang: Universitas Negeri Malang.

[4] Dahar, R. W. 2011. Teori-Teori Belajar \& Pembelajaran. Jakarta : Erlangga.

[5] Arvyaty dan Saputra, C. 2013. Pengaruh Model Pembelajaran Berbasis MAsalah (PBM) Terhadap Kemampuan Penalaran Proporsional Siswa Sekolah Menengah Pertama. Universitas Haluoleo. Jurnal Pendidikan Matematika. Vol 4 (1). Halaman: 6172.

[6] Syahputra, E. 2015. Combinatorial Thinking (Analisis Kesulitan Siswa dan Contoh Alternatif Model Matematika). PPs Universitas Negeri Medan. Makalah disajikan dalam Seminar Nasional Pendidikan Matematika HIPPMI. Medan 21 Nopember 2015. 
[7] Sukoriyanto, dkk. 2016. Students' Errors in Solving the Permutation and Combination Problems Based on Problem Solving Steps of Polya. International Education Studies. Canadian Center of Science and Education. Vol. 9, No. 2 pp 11-16; ISSN 1913-9020 E-ISSN 1913-9039.

[8] Lockwood, E. 2013. A Model of Students' Combinatorial Thinking. Unites States: Oregon State University. Journal of Mathematical Behavior 32: 251-265

[9] Arends, R. I. 2013. Learning to Teach 2. Jakarta:Salemba Humanika.

[10] Nizar, A. R. 2014. Representasi Matematis. Forum Paedagogik, Vol:VI, No: 01, pp: 110.

[11] Rezaie, M. dan Gooya, Z. 2011. What do I mean by Combinatorial Thinking?. Tehran: Shahid Beheshti University. Procedia Social and Behavioral Sciences. (11): 122-126.

[12] Melusova, J. dan Vidermanova, K. 2015. Upper-secondary Students' Strategies for Solving Combinatorial Problems. Slovakia: Constantine the Philosopher University in Nitra. Procedia-Social and Behavioral Sciences 197: 1703-1709.

[13] Lidinillah, D., A.M. 2014. Pembelajaran Berbasis Masalah (Problem Based Learning). Journal. [online]. Access on http://file.upi.edu

[14] Trianto. 2011. Mendesain Model Pembelajaran Inovatif-Progresif. Jakarta: Kencana.

[15] Arikunto, S., 2009. Prosedur Penelitian Suatu Pendekatan Praktik. Jakarta : Rineka Cipta. 